\title{
The Needham's Puzzle
}

\section{based on Explanation of the Imperial Examinations System, Human Capital Accumulation and Long-term Economic Growth}

\author{
Chen Hanyi \\ College of Economics, Shanghai University \\ Shanghai, China \\ e-mail:chenhanyi000@163.com
}

Keywords: The Needham's puzzle; Imperial examinations system; Human capital accumulation; Longterm economic growth

\begin{abstract}
This paper attempted a perspective of the imperial examination system in ancient China and human capital accumulation. A kind of new explanatory hypothesis of the Needham's Puzzle was proposed then: The different system of China and Europe resulted in the diverse path of human capital accumulation, which yielded the discrepancy of economic results as well. The purpose of the imperial examination system in ancient China was that the high talented group was selected to work in public management department and other groups with lower intelligence worked in general production department. On the contrary, Europe had been dominated under the feudal system so that groups worked in two departments randomly. The economic level was higher, by contrast, during the earlier times in China. However, the accumulation of human capital in the general production department was slow that caused slower economic growth. European had been surpassed Chinese finally.
\end{abstract}

\section{Introduction}

For quite a long time in the past, China had been the largest economy in the world. In the Song dynasty, the GDP of China had accounted for over half of the world's total. Even by 1820s, the GDP of China still accounted for $32.4 \%$ of the world's total. In modern times, however, the GDP of China declined rapidly in the world's total. The European has gone beyond Chinese in economic development naturally. Why such reversal has taken place? This is what the famous Needham puzzle deals with.Therefore, through researching macro data to analyze the impact of the current level of IPR protection on GEM listed companies' innovation output is impressive, it has important theoretical and practical significance to design further refinement of intellectual property protection policies and industrial policies which are beneficial to the development of small and medium innovative enterprises.

Domestic and foreign scholars proposed the explanation of Needham puzzle on different perspectives. The following overview was related to representation of the main explanations. Joseph Needham (1954, 1981) considered that Chinese bureaucracy had maintained the need of centralized system, while the European "aristocratic feudal system" has been conducive to the formation of the merchant class. Chinese bureaucracy has boosted the idea of "regards farming but restrains business", therefore, the invention of the craftsmen had not been stepped up a mature technology from production operation. Elvin (1973) argued that there have been large population in China so agricultural technique must be developed. Afterwards, the benefit from the improvement of agricultural technology has been devoured by a new round of population growth. The growth of population further promoted the development of agricultural technology repeatedly and China has kept the huge population by means of a higher level of agriculture technology. Lin (1995) built the model of the invention, the main idea of which was the different 
invention patterns bringing about different rates of technological progress. The early invention model has been based on the accumulation of experience and that is why natural advantages have come into being in the invention with huge population. Based on the invention mode of repeated test, it was the experimental frequency, rather than the population size determined the speed of technological progress. China had fallen behind because there was no change in invention mode. Lin (2007) has modified the above theory and attempted to achieve endogenous scientific revolution. The reason why scientific revolution had not happen in China was not that the sordid political environment restrained Chinese intellectual creativity. It was special incentive mechanism that had been provided by the Chinese imperial examination system. The genius was full of curiosity, who did not willing to learn mathematics or controlled experiment that was vital human capital for the scientific revolution. Therefore, the natural phenomena had been found by relying on casual observation barely as original scientific phase. The mathematics and control experiment of modern science did not generate a fundamental change.

In this paper, the Needham's puzzle was decomposed into four sub problems as follows. Why economic achievements were so brilliant in ancient China? Why China has fallen behind in the modern history? Why the economic level of European was very low in ancient times? Why European has risen quickly in the modern history?

This paper attempted a perspective of the bureaucracy in ancient China and human capital accumulation. Mathematical model was constructed to answer four questions. The purpose of the imperial examination system in ancient China was that the high talented group was selected to work in public management department and other groups with lower intelligence worked in general production department. The economic level was higher during the earlier times in China. However, the accumulation of human capital in the general production department was slow that caused slower economic growth. On the contrary, Europe had been dominated under the feudal system so that groups worked in every department randomly, the economic level of which was lower than that of China during the earlier times. Afterwards, the rate of human capital accumulation and economic growth had been higher.

\section{Constructing and Solving of the Model}

\section{Constructing Model.}

\section{Production Function.}

This article assumed the economy of two departments, hereafter, one department was the public management department and the other was general production department. General production department produced products, including consumable and capital, etc. At the same time, the public management department provided society public product, the social management and services. Two departments only contained human capital and material capital as production factors. Production function C-D has been constructed in this paper, as follows:

$$
\mathrm{Y}_{\mathrm{t}}=\mathrm{A}\left(\sum_{\mathrm{i}=1}^{\mathrm{m}}\left(\mathrm{MB}_{\mathrm{i}}+\mathrm{MH}_{\mathrm{it}}\right)\right)^{\alpha}\left(\sum_{\mathrm{j}=1}^{\mathrm{p}}\left(\mathrm{PB}_{\mathrm{j}}+\mathrm{PH}_{\mathrm{jt}}\right)\right)^{\beta}\left(\sum_{\mathrm{q}=1}^{\mathrm{m}+\mathrm{p}} \mathrm{k}_{\mathrm{qt}}\right)^{1-\alpha-\beta}
$$

Where $i=1,2, \ldots, m ; j=1,2, \ldots, p ; q=1,2, \ldots, m+p$

Hereby, $\mathrm{MB}_{\mathrm{i}}$ was the natural ability of ith personnel of public management department. $\mathrm{MH}_{\mathrm{it}}$ was the human capital of the ith personnel of public management department. $\mathrm{PB}_{\mathrm{j}}$ was the natural ability of jth personnel of $\mathrm{j}$. $\mathrm{PH}_{\mathrm{jt}}$ was the human capital of the $\mathrm{jth}$ personnel of general production department. $\mathrm{k}_{\mathrm{qt}}$ was the material capital of the qth personnel of two departments. $\alpha$ and $\beta$ were the parameter, which stood for the output elasticity of capital in different departments.

In this model, this article separated the innate ability from human capital. Combined with human capital, it was elements of a department added to the production function. This article assumed that every 
social department has a think tank in each issue, and think-tank growth came from the learning knowledge (last think-tank), while the efficiency of learning depended on the person's innate ability. In the process of knowledge production, if the same study was put into, the knowledge production of the group with high innate ability was higher than that of the group with lower natural ability, so growth of think-tank was faster. At the period of $t=0$, the think-tank was given specially. Based on the above assumptions, in this paper, the think-tank growth equation was built as follows:

- In China

$$
\begin{aligned}
& \mathrm{MT}_{\mathrm{t}}=\left(1+\gamma \mathrm{f}\left(\sum_{\mathrm{i}=1}^{\mathrm{m}} \mathrm{MB}_{\mathrm{i}}\right)\right) \mathrm{MT}_{\mathrm{t}-1} \\
& \mathrm{PT}_{\mathrm{t}}=\left(1+\mathrm{f}\left(\sum_{\mathrm{j}=1}^{\mathrm{p}} \mathrm{PB}_{\mathrm{j}}\right)\right) \mathrm{PT}_{\mathrm{t}-1}
\end{aligned}
$$

- In Europe

$$
\begin{aligned}
& \mathrm{MT}_{\mathrm{t}}=\left(1+\mathrm{f}\left(\sum_{\mathrm{i}=1}^{\mathrm{m}} \mathrm{MB}_{\mathrm{i}}\right)\right) \mathrm{MT}_{\mathrm{t}-1} \\
& \mathrm{PT}_{\mathrm{t}}=\left(1+\mathrm{f}\left(\sum_{\mathrm{j}=1}^{\mathrm{p}} \mathrm{PB}_{\mathrm{j}}\right) \mathrm{PT}_{\mathrm{t}-1}\right.
\end{aligned}
$$

Hereby, $\mathrm{MT}_{\mathrm{t}}$ was the think-tank of public management department. $\mathrm{PT}_{\mathrm{t}}$ was the think-tank of general production department. Think-tank growth depended on the knowledge learning of personnel, and the proportion was $\mathrm{f}($.). It was the function of all natural abilities of the department. The think-tank growth equations of general production department were exactly the same. The only difference of think-tank production function of the public management department was that there was a coefficient $\gamma$ in the equation of China. Although the group with high natural abilities worked at public management department by the imperial examination system, there was not any relationship between a good amount of knowledge itself and the think-tank of public governance. A coefficient $(\gamma)$, less than 1, was given in the paper. It showed that there was discount on the think-tank growth of public management department.

This article assumed that human capital accumulation came from the study of think-tank and the human capital accumulation equation as follows:

- In public management department

$$
\mathrm{MH}_{\mathrm{it}}=\mu \mathrm{MB}_{\mathrm{i}} \mathrm{MT}_{\mathrm{t}}
$$

- In general production department

$$
\mathrm{PH}_{\mathrm{jt}}=\mu \mathrm{PB}_{\mathrm{j}} \mathrm{PT}_{\mathrm{t}}
$$

Hereby, MHit was the human capital stock of personnel i of public management department and it was positively related to i's natural ability MBi and current Think Tank MTt. There was a discount $\mu$ from think-tank learning to human capital stock. Similarly, PHjt was the human capital stock of personnel $\mathrm{j}$ of general production department, and it was positively related to j's natural ability PBj and current Think Tank PTt. For simplicity, this article assumed that from the think-tank learning to efficiency of human capital of two departments were equal, and both of them were $\mu$.

\section{1) Budget constraint}

The budget constraint of two departments has been described, respectively.

- In public management department

$$
\mathrm{mc}_{\mathrm{it}}+\mathrm{ms}_{\mathrm{it}}=\mathrm{mw}_{\mathrm{t}} \mathrm{MB}_{\mathrm{i}}+\mathrm{r}_{\mathrm{t}} \mathrm{k}_{\mathrm{it}}
$$




$$
\mathrm{k}_{\mathrm{i}, \mathrm{t}+1}=\mathrm{ms}_{\mathrm{it}}
$$

Hereby, $\mathrm{mc}_{\mathrm{it}}$ was the consumption of the ith personnel of public management department. $\mathrm{ms}_{\mathrm{it}}$ was ith personnel 's savings on public management department. $\mathrm{mw}_{\mathrm{t}}$ was the current salary of public management department. $\mathrm{MB}_{\mathrm{i}}$ was the natural ability of $\mathrm{i}$ on public management department. Here, we assumed that i' income only related to department wage level and natural ability. Namely, it was the product of department salary level and natural abilities, rather than the product of department salary level and human capital ${ }^{1}$. I's output came from his natural ability and natural endowment of period t. $r_{t}$ was the interest rate for the period $t$. $k_{i t}$ was $i$ material capital stock. The next material capital stock came from the transformation of the current savings.

- In general production department

$$
\begin{aligned}
& \mathrm{pc}_{\mathrm{jt}}+\mathrm{ps}_{\mathrm{jt}}=\mathrm{pw}_{\mathrm{t}} \mathrm{PB}_{\mathrm{j}}+\mathrm{r}_{\mathrm{t}} \mathrm{k}_{\mathrm{jt}} \\
& \mathrm{k}_{\mathrm{j}, \mathrm{t}+\mathrm{l}}=\mathrm{ps}_{\mathrm{jt}}
\end{aligned}
$$

Hereby, $\mathrm{pc}_{\mathrm{jt}}$ was the consumption of the jth personnel of general production department. $\mathrm{ps}_{\mathrm{jt}}$ was $\mathrm{j}$ 's savings. $\mathrm{pw}_{\mathrm{t}}$ was the salary of current general production department. $\mathrm{PB}_{\mathrm{j}}$ was the natural ability of general production department. And their product was $j$ ' $s$ income. $r_{t}$ was the current interest rates. $k_{j t}$ was the material capital stock of $\mathrm{j}$ and it was completed by the previous savings.

2) The utility function and the objective function

a) The utility function

In the standard Ramsey model, the utility function was generally assumed a CRRA type, i.e:

$$
\mathrm{u}(\mathrm{c})=\frac{\mathrm{c}^{1-\gamma}-1}{1-\gamma}
$$

In this paper, in order to simplify the model, the utility function was directly assumed the logarithmic form, namely:

$$
\mathrm{u}(\mathrm{c})=\ln \mathrm{c}
$$

\section{b) The objective function}

Now, the objective function of personnel on two departments has been described, respectively.

- In public management department

$$
\mathrm{MV}_{\mathrm{i}}=\sum_{\mathrm{t}=0}^{\infty} \rho^{\mathrm{t}} \mathrm{u}\left(\mathrm{mc}_{\mathrm{it}}\right)
$$

- In general production department

$$
\mathrm{PV}_{\mathrm{j}}=\sum_{\mathrm{t}=0}^{\infty} \rho^{\mathrm{t}} \mathrm{u}\left(\mathrm{pc}_{\mathrm{jt}}\right)
$$

where, $\rho$ was the discount rate of inter-temporal consumption, $0<\rho<1$.

\section{B. Solving the model}

To solve this model, it was necessary to work out the Euler equations first.

\footnotetext{
${ }^{1}$ The current department's average wage has been given in accordance with the generally assumption. The average wages of the department multiplied by the current human capital stock was the current income of personnel, while the current human capital stock was a function of natural ability and level of current think-tank. To simplify the constraint conditions we assumed directly that the average wages of the department multiplied by the natural ability was the income of personnel for the explicit solutions of the model.
} 
For public management department, the Euler equation:

$$
\mathrm{u}^{\prime}\left(\mathrm{c}_{\mathrm{it}}\right)=\rho \mathrm{u}^{\prime}\left(\mathrm{c}_{\mathrm{i}, \mathrm{t+1}}\right) \mathrm{r}_{\mathrm{t}+1}
$$

For normal production, the Euler equation:

$$
\mathrm{u}^{\prime}\left(\mathrm{c}_{\mathrm{jt}}\right)=\rho \mathrm{u}^{\prime}\left(\mathrm{c}_{\mathrm{j}, \mathrm{t}+1}\right) \mathrm{r}_{\mathrm{t}+1}
$$

Based on (2.15) and (2.16), two Euler equations showed that the maximization utility of the personnel on two departments, the condition of which was the adjacent two phases of the marginal utility of consumption on the present value should be equal.

To get the explicit solutions, the previous utility function $u\left(c_{t}\right)=\operatorname{lnc}_{t}$ was substituted as hypothesis.

From (2.15) and (2.16), here was a balanced growth path:

$$
\frac{\mathrm{c}_{\mathrm{i}, \mathrm{t}+1}}{\mathrm{c}_{\mathrm{i}, \mathrm{t}}}=\rho \mathrm{r}_{\mathrm{t}+1}=\mathrm{g}_{\mathrm{c}}{ }^{*}
$$

(2.17) showed if the actual reward was higher than the rate of future consumption, whose consumption would rise. On the other hand, if the actual reward was higher than the rate of future consumption, whose consumption would reduce. On the balanced growth path, they were equal by coincidence.

\section{Result and discussion}

The economic growth rate of China and the west was worked out from the model respectively.

- In China

$$
\mathrm{g}_{\mathrm{e}}=\left(1+\gamma \mathrm{f}\left(\sum_{\mathrm{i}=1}^{\mathrm{m}} \mathrm{MB}_{\mathrm{i}}\right)\right)^{\frac{\alpha}{\alpha+\beta}}\left(1+\mathrm{f}\left(\sum_{\mathrm{j}=1}^{\mathrm{p}} \mathrm{PB}_{\mathrm{j}}\right)\right)^{\frac{\beta}{\alpha+\beta}}
$$

- In Europe

$$
\mathrm{g}_{\mathrm{w}}=\left(1+\mathrm{f}\left(\sum_{\mathrm{i}=1}^{\mathrm{m}} \mathrm{MB}_{\mathrm{i}}\right)\right)^{\frac{\alpha}{\alpha+\beta}}\left(1+\mathrm{f}\left(\sum_{\mathrm{j}=1}^{\mathrm{p}} \mathrm{PB}_{\mathrm{j}}\right)\right)^{\frac{\beta}{\alpha+\beta}}
$$

Integrating (4.2) - (4.7), the two equations above could be rewritten:

$$
\begin{gathered}
\mathrm{g}_{\mathrm{e}}=\left(\frac{\mathrm{g}_{\mathrm{eMH}}}{\mu \sum_{\mathrm{i}=1}^{\mathrm{m}} \mathrm{MB}_{\mathrm{i}}}\right)^{\frac{\alpha}{\alpha+\beta}}\left(\frac{\mathrm{g}_{\mathrm{ePH}}}{\mu \sum_{\mathrm{j}=1}^{\mathrm{p}} \mathrm{PB}_{\mathrm{j}}}\right)^{\frac{\beta}{\alpha+\beta}} \\
\mathrm{g}_{\mathrm{w}}=\left(\frac{\mathrm{g}_{\mathrm{wMH}}}{\mu \sum_{\mathrm{i}=1}^{\mathrm{m}} \mathrm{MB}_{\mathrm{i}}}\right)^{\frac{\alpha}{\alpha+\beta}}\left(\frac{\mathrm{g}_{\mathrm{wPH}}}{\mu \sum_{\mathrm{j}=1}^{\mathrm{p}} \mathrm{PB}_{\mathrm{j}}}\right)^{\frac{\beta}{\alpha+\beta}}
\end{gathered}
$$

Accordingly, $\mathrm{g}_{\mathrm{e}}$ was the economic growth rate of China. gw was the economic growth rate of the west. $\mathrm{g}_{\mathrm{e} M H}$ and $\mathrm{g}_{\mathrm{ePH}}$ were the growth rate of human capital stock of Chinese public management department and general production department, respectively. $\mathrm{g}_{\mathrm{wMH}}$ and $\mathrm{g}_{\mathrm{wPH}}$ were the growth rate of human capital stock of western public management department and general production department, respectively. 
The result of (2.20) and (2.21) showed that economic growth of China and the west only depended on the growth of human capital stock of each department. However, the growth way of the Chinese and western human capital stock was different. Based on (2.2) - (2.7), the growth rate of human capital stock of China and western countries were shown below:

$$
\begin{aligned}
& \mathrm{g}_{\mathrm{eMH}}=\left(1+\gamma \mathrm{f}\left(\sum_{\mathrm{i}=1}^{\mathrm{m}} \mathrm{MB}_{\mathrm{i}}\right)\left(\mu \sum_{\mathrm{i}=1}^{\mathrm{m}} \mathrm{MB}_{\mathrm{i}}\right)\right. \\
& \mathrm{g}_{\mathrm{ePH}}=\left(1+\mathrm{f}\left(\sum_{\mathrm{j}=1}^{\mathrm{p}} \mathrm{PB}_{\mathrm{i}}\right)\left(\mu \sum_{\mathrm{j}=1}^{\mathrm{p}} \mathrm{PB}_{\mathrm{i}}\right)\right. \\
& \mathrm{g}_{\mathrm{wMH}}=\left(1+\mathrm{f}\left(\sum_{\mathrm{i}=1}^{\mathrm{m}} \mathrm{MB}_{\mathrm{i}}\right)\left(\mu \sum_{\mathrm{i}=1}^{\mathrm{m}} \mathrm{MB}_{\mathrm{i}}\right)\right. \\
& \mathrm{g}_{\mathrm{wPH}}=\left(1+\mathrm{f}\left(\sum_{\mathrm{j}=1}^{\mathrm{p}} \mathrm{PB}_{\mathrm{i}}\right)\left(\mu \sum_{\mathrm{j}=1}^{\mathrm{p}} \mathrm{PB}_{\mathrm{i}}\right)\right.
\end{aligned}
$$

Hereby, $\mathrm{g}_{\mathrm{e} M \mathrm{H}}$ and $\mathrm{g}_{\mathrm{ePH}}$ were the growth rate of human capital stock of Chinese public management department and general production department, respectively. $\mathrm{g}_{\mathrm{wMH}}$ and $\mathrm{g}_{\mathrm{wPH}}$ were the growth rate of human capital stock of western public management department and general production department, respectively.

From (2.22) - (2.25), we could found that the human capital stock of China and the west both depended on the natural ability of the personnel of each department. The group with high natural abilities focused on public management department through the imperial examination system so that the sum initial investment of natural ability of public management department in China would be higher than that of the West. But the accumulation of human capital for the imperial examinations to improve the efficiency of public management department's productivity was questionable (i.e. $0<\gamma<1$, and if $\gamma$ is small enough, China's growth rate of human capital in public management department would be lower than that of the west, even if there was a higher natural abilities of the department in total. ). Therefore, the growth rate of human capital in China would not higher than that of the west. At the same time, either the initial investment of sum innate ability or the growth rate of human capital of general production department in China was lower than that of the west. As long as the initial $\alpha$ was larger, the public management department's contribution to the output was bigger than that of the general production department. It was why the ancient Chinese economic gained more than that of the west, while it had been flipped in modern times.

Stated thus, the model indicated that the different system of China and Western leading to the different path of human capital accumulation, yielding the different economic results.

\section{Conclusion}

The comparative analysis of different political system between Chinese and European before modern times was revealed in this article and it was combined with the human capital theory to explain Needham Puzzle. The conclusion was the answers of four sub questions defined by Needham puzzle in the first chapter.

- Why economic achievements were so brilliant in ancient China?

As a result of open bureaucracy in ancient China, the most talented person had been elected to join bureaucratic group and administer the state power, who worked in public management department to participate in the public governance. The remaining persons with lower talent worked in general 
production department to participate in the general production activities. In ancient times, the accumulation of human capital was very low so that a person relied on their own innate ability for production activities basically. The contribution of public management department was greater than that of the general production department and there were larger quantity of outstanding human resources in public management department that also led to the brilliant economic achievements in ancient China.

- Why China has fallen behind in the modern history?

It was uncertainty that participators would work in public management department or not. The imperial examination system attracted the participator greatly. All human capital accumulated on the subjects of imperial examination. What is more, the accumulation of human capital has been wasted. Because there was accumulation of public governance or general production activities regardless of all consequences, the effectiveness of which was questionable. The efficiency of public management department in China had been stagnant for a long time, meanwhile, less talented group predominated economic growth in the production department with low efficiency of human capital accumulation. In this way, China has been beyond the west slowly, which has fallen behind in modern times.

- Why the economic level of European was very low in ancient times?

Ancient West had been dominated by typical feudal system, called "power on hereditary, economy on fiefdoms." Because the power of the government was obtained through inheritance only, the western public management department and general production department was delimited in one direction. If one wanted to work in public management department, the chance was obtained by inheriting the title only and if one had the chance to work in public management department, would also work in the general production department, but they obviously didn't want to choose the latter, because according to our model, wages of public management department was higher than that of general production department at first. Under this system, the productivity of general production department would be higher than China's, but the productivity of public management department was far less than that of China. Because the public management department's contribution was large to the output, the economy of the west in ancient times was extremely low.

- Why European has risen quickly in the modern history?

The person who worked in two departments was distributed randomly in the west. From the very beginning the human capital stock of general production department has been higher than China's. From time to time, human capital has been accumulated. Although the productivity of modern western public management department has been on a very low level, the productivity of general production department would rapidly rise and outstrip that of China. When the marginal productivity difference of western public management department and the general production department has reached a critical value, revolution would break out. Revolution had changed the western political system, thus greatly improved the productivity of public management department, meanwhile, it was not at the expense of reducing productivity of general production department. In this way, there was blowout of the western economy on a short period, which surpassed China very quickly in modern times.

\section{References}

[1] Lin J Y. The Needham puzzle: Why the industrial revolution did not originate in China[J]. Economic development and cultural change, 1995: 269-292.

[2] Lin J Y. Needham Puzzle, Weber Question and China's Miracle: Long Term Performance since the Song Dynasty [J]. Journal of Peking University 
[3] Diamond,J. Guns, Germs and Steel . 1999

[4] Elvin,M.The Pattern ofthe Chinese Past 1973

[5] Wen G J. Why was china trapped in an agrarian society? An economic geographical approach to the needham puzzle[J]. Frontiers of Economics in China, 2011, 6(4): 507-534.

[6] Chenkunting. Gongliutang. Great Divergence. Modeling analysis_culture, institutional and economic growth [J]. Journal of Beijing university (Philosophy and Social Sciences), 2006, 43(2): 114-124.

[7] Pijianbo. The interpretation of the Needham Puzzle - where do we stand [J].Economics (quarterly), 2006, 6(1).

[8] Wenguanzhong. The changes of Chinese Territory and desirous abandon of agricultural societyNeedham Puzzle of Economic Geography [J]. Economics (quarterly), 2005, 4(2): 519-540.

[9] Yaoyang. Diyu, System and Needham Puzzle [J]. Reading, 2008 (1).

[10] Yaoyang. High -level trap_— the reinspection of Needham Puzzle [J]. Economic research, 2003, 1: 71-79.

[11] Zhaohongjun. Needham puzzle: Economists Should Accept the Old Solution or the New One? [J]. Economics (quarterly), 2009, 7(3): 1615-1645 